\title{
Gender is not a Prognostic Factor for Familial Mediterranean Fever
}

\author{
Ailevi Akdeniz Ateşinde Cinsiyetin Prognoza Etkisi Yoktur \\ $\underline{\text { Nazife Sule Yasar Bilge }}{ }^{1}, \underline{\text { Erdal Bodakc1 }}^{1}, \underline{\text { Ugur Bilge }}^{2}$, Timucin Kasifoglu $^{1}$ \\ ${ }^{1}$ Division of Rheumatology, Department of Internal Medicine, Eskisehir Osmangazi University \\ ${ }^{2}$ Department of Family Medicine, Eskisehir Osmangazi University
}

\begin{abstract}
Objectives: Familial Mediterranean fever (FMF) is the most common hereditary auto-inflammatory disease. Our aim in the current study was to evaluate the relation between gender and clinical findings, the severity of disease and treatment compliance in FMF patients.

Materials and Methods: Medical records of the 150 FMF patients were retrospectively evaluated.

Disease severity scores were evaluated with the international severity score system for familial

Mediterranean fever (ISSF), treatment compliance of the patients was evaluated with six-item modified

Morisky scale and compared between males and females.

Results: Of the 150 patients, 87 (58 \%) were female and 63 (42\%) were male. Erysipelas like erythema (ELE) was more common in females $(51.70 \%$ vs $30.90 \%, p=0.03)$ and myalgia were more common in males $(31.03 \%$ vs $36.50 \%, \mathrm{p}=0.015)$. Other clinical findings were at similar frequencies.

The ISSF scores of the groups were similar $(2.93 \pm 2.05$ vs $3.12 \pm 2.21, \mathrm{p}=0.716)$.

The motivation for treatment and knowledge levels were the same in both groups $(p=0.228$ and $p=0.112$, respectively).

Conclusion: Clinical findings, ISSF scores and treatment compliance of the FMF patients in both sexes are similar. The gender of the patient does not affect the clinical course of disease in FMF patients.

Keywords: Familial mediterranean fever, severity, sex, treatment compliance
\end{abstract}

$\ddot{O} z$

Giriş: Ailevi Akdeniz ateşi (AAA) en sık görülen herediter, oto-inflamatuar hastalıktır. Bu çalşmada amacımız AAA hastalarında cinsiyet ve klinik bulgular, hastalık şiddeti ve tedavi uyumu arasındaki ilişkiyi incelemektir.

Materyal ve Metot: AAA tanılı 150 hastanın arşiv dosyaları retrospektif olarak incelendi. Hastalık şiddeti uluslararası AAA şiddet skorlama sistemi (ISSF) ile, tedavi uyumlar1 6 maddeli modifiye Morisky ölçeği ile değerlendirildi ve cinsiyetler arası kiyaslandı.

Bulgular: AAA tanılı 150 hastanın 87'si (\%58) kadın ve 63’ü (\%42) erkekti. Erezipel benzeri eritem (EBE) kadınlarda (\%51,70 ve \%19, $\mathrm{p}=0,03)$ ve miyalji erkeklerde daha siktı $(\% 31$ ve $\% 36,50, \mathrm{p}=0,015)$. Diğer klinik bulgular cinsiyetler arası farklılık göstermedi. ISSF skorları arasında da farklılık saptanmadı $(2,93 \pm 2,05$ ve $3,12 \pm 2,2 ; \mathrm{p}=0,716)$. Tedavi uyumu ve bilgi düzeyleri her iki grupta benzerdi. (sirasıyla $\mathrm{p}=0,228$ ve $\mathrm{p}=0,112$,).

Sonuç: AAA hastalarında klinik bulgular, ISSF skorları, tedavi uyumu cinsiyetler arası farklılık göstermemektedir. AAA hastalarında cinsiyetin prognoz üzerine etkisi yoktur.

Anahtar kelimeler: Ailevi akdeniz ateşi, cinsiyet, şiddet, tedavi uyumu

Yazışma Adresi / Correspondence:

Nazife Sule Yasar Bilge

e-mail: suleyasar@yahoo.com

Date of submission: 29.08.2019

Date of admission: 21.11.2019

\section{Introduction}

Familial Mediterranean fever (FMF) is the most common hereditary autoinflammatory disease and characterized by attacks of fever and serositis. ${ }^{1}$ Even though the frequency and severity of attacks affect the quality of life of the patients, there is very limited data about which factors have an influence on disease course. Until now male sex, arthritis, family history of amyloidosis and 
homozygous M694V mutation are supposed to have a relation with the development of amyloidosis. ${ }^{2}$ But there is not any data about the relation between gender and severity of FMF.

Some autoimmune diseases such as rheumatoid arthritis or systemic lupus erythematosus tend to be more common in females and some complications such as rheumatoid vasculitis are known to be more frequent in males. But autoinflammatory diseases are known to be equally seen in both sexes. Also, there isn't much data about the accumulation of the clinical findings in either sex.

As FMF is the most common autoinflammatory disease and there isn't any knowledge in the current literature about the differences in the sex and the course of the disease, our aim in the current study was to evaluate the relation between gender and clinical findings, the severity of disease and treatment compliance.

\section{Material and Methods}

The study includes 150 FMF patients followed by the rheumatology department in a tertiary center. Patients were diagnosed as FMF according to Livneh criteria. ${ }^{3}$ All FMF patients admitted to the outpatient clinic from January 2017 to January 2018 were included in the study. Medical records of the patients were evaluated retrospectively and sex, age at the time of study, age at diagnosis, age at onset of the symptoms, presence of clinical findings such as fever, peritonitis, pleuritis, erysipelas-like erythema (ELE), myalgia and arthritis, complications like amyloidosis and chronic renal failure $(\mathrm{CRF})$ and colchicine dosage were recorded.

MEFV gene mutations were analyzed with PCR restriction fragment length polymorphism (PCRRFLP).

Disease severity scores were evaluated with the international severity score system for familial Mediterranean fever (ISSF) which developed by Demirkaya et al. ${ }^{4}$

Treatment compliance of the patients was evaluated with six-item modified Morisky scale. ${ }^{5}$

ISSF score system

This system includes 10 items ( 9 main, 4th is divided 2 as a and b). Presence of item $4 \mathrm{~b}$ (frequency of attacks $>2$ per month) is equal to 2 points and the presence of other items is equal to 1 point. A total score $\geq 6$ is revealed as a severe disease, 3-5 means intermediate disease and a score $\leq 2$ is interpreted as a mild disease. ${ }^{4}$

\section{Six-item modified Morisky scale}

Response choices are "yes" and "no" in the six-item Modified Morisky Scale. The score is 1 for "yes" option and 0 for "no" option in questions 2 and 5, and 0 for "no" option and 1 for "yes" option in questions 1, 3, 4 and 6. Subscale scores of 0 or 1 in questions 1,2 and 6 refer to low motivation, and the score over 1 refers to high motivation. Subscale scores of 0 or 1 in questions 3, 4 and 5 suggest a low level of knowledge and the score over 1 suggests a high level of knowledge. ${ }^{5}$

Written informed consent was obtained from all patients and the study was approved by the Clinical Research Ethics Committee (decision no. 80558721/G-310, Nov, 2017).

\section{Statistics}

Continuous data are presented as mean \pm standard deviation. Categorical data are presented as percentage $(\%)$. The relevance of data to the normal distribution is surveyed with the Shapiro Wilk test. Mann-Whitney $U$ test is used to compare two groups which are not normally distributed. Pearson Ki-Kare, Continuity Correction Chi-Square Test, Fisher's Exact Chi-Square Test, and Pearson Exact Chi-Square Test are used for cross table analysis. IBM SPSS Statistics 21.0 (IBM Corp. Released 2012. IBM SPSS Statistics for Windows, Version 21.0. Armonk, NY: IBM Corp.) is used for analysis. A value $\mathrm{p}<0.05$ is used for statistical significance. 


\section{Results}

The study population consisted of 150 FMF patients. Of the 150 patients, 87 (58.00\%) was female and $63(42.00 \%)$ was male. The mean age of the patients was $35.71 \pm 13.22$ yrs. Age at time of the study, age at onset of disease age at diagnosis were compared between groups and there wasn't any difference. (Table 1)

Table 1. The comparison of the demographic, clinical features and Morisky scale results between female and male FMF patients

\begin{tabular}{|c|c|c|c|c|}
\hline & $\begin{array}{l}\text { Female } \\
\text { (n: 87) }\end{array}$ & $\begin{array}{l}\text { Male } \\
(\mathrm{n}: 63)\end{array}$ & $\mathrm{p}$ \\
\hline \multicolumn{5}{|c|}{$\begin{array}{l}\text { Demographic features } \\
\text { (Median (Q1 - Q3)) }\end{array}$} \\
\hline \multicolumn{2}{|c|}{ Age (yrs) } & $37.00(25.00-44.00)$ & $33.00(23.00-43.00)$ & 0.573 \\
\hline \multicolumn{2}{|c|}{ Age at onset of disease (yrs) } & $15.00(9.00-23.00)$ & $15.00(8.00-22.00)$ & 0.804 \\
\hline \multicolumn{2}{|c|}{ Age at diagnosis (yrs) } & $26.00(17.00-37.00)$ & $24.00(15.00-34.00)$ & 0.373 \\
\hline \multicolumn{2}{|c|}{ Clinical features $(\mathrm{n}(\%))$} & & & $x^{2} ; p$ \\
\hline \multicolumn{2}{|c|}{ Fever } & $74(85.05 \%)$ & $55(87.30 \%)$ & $0.905 ; 0.892$ \\
\hline \multicolumn{2}{|l|}{ Peritonitis } & $79(90.80 \%)$ & $58(92.10 \%)$ & $0.814 ; 1.000$ \\
\hline \multicolumn{2}{|l|}{ Pleuritis } & $41(47.10 \%)$ & $26(41.30 \%)$ & $3.133 ; 0.209$ \\
\hline \multicolumn{2}{|l|}{ Vasculitis } & $10(11.40 \%)$ & $3(4.80 \%)$ & $2.101 ; 0.382$ \\
\hline \multicolumn{2}{|l|}{ ELE } & $45(51.70 \%)$ & $19(30.10 \%)$ & $7.027 ; \mathbf{0 . 0 3 0}$ \\
\hline \multicolumn{2}{|l|}{ Arthritis } & $20(22.98 \%)$ & $15(23.80 \%)$ & $0.058 ; 0.971$ \\
\hline \multicolumn{2}{|l|}{ Myalgia } & $27(31.03 \%)$ & $23(36.50 \%)$ & $8.428 ; \mathbf{0 . 0 1 5}$ \\
\hline \multicolumn{2}{|l|}{ Amyloidosis } & $10(11.40 \%)$ & $12(15.10 \%)$ & $3.165 ; 0.223$ \\
\hline \multicolumn{2}{|l|}{ CRF } & $2(2.30 \%)$ & $5(7.93 \%)$ & $4.370 ; 0.118$ \\
\hline \multicolumn{2}{|l|}{ Morisky scale results } & & & $x^{2} ; p$ \\
\hline \multirow[t]{2}{*}{ Level of knowledge } & Low & $12(13.80 \%)$ & $2.521 ; 0.11$ & \multirow{2}{*}{$2.52 ; 0.112$} \\
\hline & High & $75(86.20 \%)$ & $47(38.50 \%)$ & \\
\hline \multirow[t]{2}{*}{ Level of motivation } & Low & $25(28.70 \%)$ & $1.455 ; 0.23$ & \multirow{2}{*}{$1.46 ; 0.228$} \\
\hline & High & $62(71.30 \%)$ & $39(61.90 \%)$ & \\
\hline
\end{tabular}

ELE: erysipel like eryhthema, CRF: chronic renal failure

The clinical findings of the males and females were compared and the frequency of fever, peritonitis, pleuritis, vasculitis, arthritis, amyloidosis and chronic renal failure did not show a statistically significant difference between two sexes. But ELE was more common in females (51.70\% vs 30.10\%, p: 0.03 ) and myalgia was more common in males (31\% vs 36.50\%, p:0.015). (Table 1)

The ISSF scores of the groups were compared; the difference was not statistically significant (2.93 \pm 2.05 vs $3.12 \pm 2.21$, p: 0.716$)$. Nineteen of the patients (9 female) had severe disease according to ISSF score (p: 0.541).

Of the 150 patients 133 (88.70\%) had MEFV mutation analysis results (female: 64, male: 59, p: 0.08). Fifteen (10\%) of the 133 patients did not have detectable MEFV mutation (female: 13 , male: 2 , p: 0.008). The most common mutation in the study population was homozygous $M 694 \mathrm{~V}$ mutation; 21 of the females $(24.10 \%)$ and 17 of the males $(26.98 \%)$ and the difference was not statistically significant (p: 0.69). Heterozygous $M 694 \mathrm{~V}$ mutation also had similar rates in both groups (p: 0.745). A detailed list of the MEFV mutation analysis is shown in Table 2. 
All patients were receiving colchicine therapy, 8 patients were receiving anakinra and 5 patients were receiving canakinumab. Dosage and duration of colchicine treatment did not show a significant difference between groups (p: 0.608and p: 0.868, respectively).

Table 2. MEFV mutation analysis of females and males

\begin{tabular}{|l|c|c|}
\hline MEFV mutations & $\begin{array}{c}\text { Female (n:87) } \\
(\mathrm{n}(\%))\end{array}$ & $\begin{array}{c}\text { Male (n:63) } \\
(\mathrm{n}(\%))\end{array}$ \\
\hline Homozygous $M 694 V$ & $21(24.14 \%)$ & $17(27,00 \%)$ \\
\hline Heterozygous $M 694 V$ & $17(19.54 \%)$ & $11(17.50 \%)$ \\
\hline Heterozygous E148Q & $2(2.29 \%)$ & 0 \\
\hline M694V+M680I & $1(1.14 \%)$ & $2(7.93 \%)$ \\
\hline M694V+R202Q & $2(2.29 \%)$ & $4(6.35 \%)$ \\
\hline Heterozygous $M 680 I$ & $4(4.60 \%)$ & $4(6.35 \%)$ \\
\hline M694V+E148Q & $2(2.29 \%)$ & $6(9.52 \%)$ \\
\hline M694V+V726A & 0 & 0 \\
\hline M694V+M694I & $1(1.14 \%)$ & $2(3.17 \%)$ \\
\hline Homozygous $M 680 I$ & $1(1.14 \%)$ & $3(4.76 \%)$ \\
\hline M680I+V726A & $1(1.14 \%)$ & 0 \\
\hline V726A+R761H & $1(1.14 \%)$ & $1(1.58 \%)$ \\
\hline M694V+R761H & $1(1.14 \%)$ & $1(1.58 \%)$ \\
\hline Heterozygous $V 726 A$ & $1(1.14 \%)$ & 0 \\
\hline E148Q+V726A & $1(1.14 \%)$ & 0 \\
\hline M680I+E148Q & $3(3.45 \%)$ & $1(1.58 \%)$ \\
\hline M684V+V726A & 0 & 0 \\
\hline M694V+V726A+R202Q & $1(1.14 \%)$ & 0 \\
\hline Homozygous $R 202 Q$ & $1(1.14 \%)$ & $2(3.17 \%)$ \\
\hline Negative & $13(15.00 \%)$ & $4(6.34 \%)$ \\
\hline Not analysed & $13(15.00 \%)$ & \\
\hline
\end{tabular}

To analyze the compliance to treatment 6-item modified Morisky scale was used and motivation and knowledge levels did not show a significant difference (p:0.228 and p:0.112, respectively). (Table 1)

\section{Discussion}

In the current study, we compared the demographic and clinical findings, severity scores, $M E F V$ mutation analysis and the compliance to treatment of the male and female FMF patients. ELE was more common in females and myalgia was more common in males but other findings did not show a statistically significant difference.

FMF is the most common monogenic autoinflammatory disease and Turkey is one of the most commonly seen regions. Amyloidosis is the most important complication which may result in chronic renal failure. In a previous study, attack frequency, younger age at onset of disease, having homozygous M694V mutation, family history of amyloidosis and CRF were tending to cause amyloidosis. ${ }^{2}$ Until now, there isn't a study focusing on the relationship between gender and disease severity. We have analyzed the clinical findings and ISSF scores of the patients and compared between two sexes. Fever, peritonitis, pleuritis, vasculitis, arthritis, amyloidosis and CRF were in the same frequency in two groups except for myalgia and ELE. ELE was one of the components of severity scoring system by Pras et al..$^{6}$ In the current study, ELE was more frequent in females but the difference did not have an influence on disease severity. Also, myalgia 
was more common in males and it was found to be correlated with severe disease in a study by Mor et $\mathrm{al}^{7}$, but we did not find such a correlation. The ISSF score did not show a significant difference between males and females. Development of amyloidosis and CRF were also similar in two groups. The distribution of MEFV mutations was similar in females and males. The ratio of patients who did not have a detectable MEFV mutation was higher in females but this result is not correlated with any of the clinical findings.

FMF is characterized with serositis attacks and the frequency and severity of attacks affect the course of the disease. To provide a better quality of life and prevent the development of amyloidosis, subgroups of FMF are tried to be defined. As an example, early onset disease has a more severe course when compared with the late-onset disease. ${ }^{8}$ But when we compared the ages of onset of disease in two groups there was not any difference, as the ages at diagnosis were also similar.

Colchicine compliance is an important factor to take under control of the attacks and preventing amyloidosis. We have evaluated the compliance to colchicine treatment with 6 items modified Morisky scale. Vural et al. conducted a study to test reliability and validity of the Modified Morisky Scale, where they administered the Modified Morisky Scale as pre-test and post-test to a group of 35 patients taking medications for at least six months for the treatment of chronic disease. They found out that the Turkish version of the Modified Morisky Scale was a short and reliable tool that is easy to administer to test the levels of motivation and knowledge separately. That is why we used this scale in the present study. ${ }^{5}$

The level of knowledge and motivation was high in all FMF patients regardless of gender. As colchicine is a drug which is used lifelong, to inform the patients by doctors and the compliance of the patients is very important.

The small number of the sample size is the most important limitation of our study. Maybe a more detailed analysis with a larger number of patients could be more effective to find a difference between two sexes. Also, the retrospective design of the study is another limitation. The scoring is based on medical records and we do not have longterm results, maybe damage features will accumulate in one sex resulting in a difference but unfortunately we do not have any prospective data.

In conclusion, there are many factors affecting the severity of disease in FMF but gender does not seem to be one of them in our study cohort.

\section{Conflict of interest}

None

\section{References}

1. Sari I, Birlik M, Kasifoglu T. Familial Mediterranean fever: an updated review. Eur J Rheumatol 2014;1:21-3.

2. Kasifoglu T, Bilge SY, Sari I, et al. Amyloidosis and its related factors in Turkish patients with familial Mediterranean fever: a multicentre study. Rheumatology (Oxford) 2014;53(4):741-5.

3. Livneh A, Langevitz P, Zemer D, et al. Criteria for the diagnosis of familial Mediterranean fever. Arthritis Rheum. 1997;40(10):1879-85 (doi:10.1002/art.1780401023).

4. Demirkaya E, Acikel C, Hashkes P, et al. FMF Arthritis Vasculitis and Orphan disease Research in pediatric rheumatology (FAVOR). Development and initial validation of 
international severity scoring system for familial Mediterranean fever (ISSF). Ann Rheum Dis. 2016;75(6):1051-6.

5. Vural B, Acar OT, Topsever P, Filiz TM. Reliability And Validity Of Turkish Version Of Modified Morisky Scale. Tur Fam Physician. 2012;3(2):17-20.

6. Pras E, Livneh A, Balow Jr JE, ve ark. Clinical differences between North African and Iraqi Jews with familial Mediterranean fever. Am J Med Genet 1998;75(2):216-9.

7. Mor A, Shinar Y, Zaks N, et al. Evaluation of disease severity in familial Mediterranean fever. Semin Arthritis Rheum. 2005;35(1):57-64.

8. Sönmez HE, Esmeray P, Batu ED, et al. Is age associated with disease severity and compliance to treatment in children with familial Mediterranean fever? Rheumatol Int. 2019;39(1):83-7. 